\title{
Augmented in vitro expression of CCL2 by peripheral blood mononuclear cells is associated with the presence of interstitial lung disease in patients with systemic sclerosis
}

\author{
Zwiększona in vitro ekspresja CCL2 w komórkach jednojądrowych krwi obwodowej \\ wiąże się z obecnością śródmiąższowej choroby płuc u chorych na twardzinę układowa
}

\author{
Krzysztof Kowal' ${ }^{1}$ Marek Bielecki ${ }^{2}$, Ewa Sacharzewska ${ }^{3}$, Paweł Bernatowicz ${ }^{4}$, Wojciech Naumnik ${ }^{4,5}$, \\ Otylia Kowal-Bielecka ${ }^{6}$
}

\begin{abstract}
${ }^{1}$ Department of Allergology and Internal Medicine, Medical University of Bialystok
2Department of Orthopedics and Traumatology, Medical University of Bialystok

${ }^{3}$ Center of Experimental Medicine, Medical University of Bialystok

${ }^{4}$ Department of Clinical Molecular Biology, Medical University of Bialystok

${ }^{5}$ Department of Lung Diseases and Tuberculosis, Medical University of Bialystok

${ }^{6}$ Department of Rheumatology and Internal Diseases, Medical University of Bialystok

${ }^{1}$ Klinika Alergologii i Chorób Wewnętrznych Uniwersytetu Medycznego w Białymstoku

2Klinika Ortopedii i Traumatologii Uniwersytetu Medycznego w Białymstoku

${ }^{3}$ Centrum Medycyny Eksperymentalnej Uniwersytetu Medycznego w Białymstoku

4Zakład Klinicznej Biologii Molekularnej Uniwersytetu Medycznego w Białymstoku

${ }^{5}$ Klinika Chorób Płuc i Gruźlicy Uniwersytetu Medycznego w Białymstoku

${ }^{6}$ Klinika Reumatologii i Chorób Wewnętrznych Uniwersytetu Medycznego w Białymstoku
\end{abstract}

Słowa kluczowe: twardzina układowa, CCL2, włóknienie płuc.

Key words: systemic sclerosis, CCL2, pulmonary fibrosis.

\section{Sum mary}

Aim of the study: Scleroderma-related interstitial lung disease (SLD) is the major cause of mortality in patients with systemic sclerosis (SSC). CCL2 is a chemokine which exerts strong pro-inflammatory and pro-fibrotic function. In the present study we aimed to evaluate in vitro expression of CCL2 by the peripheral blood mononuclear cells (PBMC) of SSC patients with and without SLD.

Material and methods: Twenty-three SSc patients (11 with and 12 without SLD) and 12 age- and sex-matched healthy controls (HC) were included in the study. Expression of RNA was assessed by means of real-time polymerase chain reaction and CCL2 concentrations - with commercially available ELISA kits in PBMC cultured with and without stimulation with lipopolysaccharide (LPS).

Results: Both, spontaneous expression of CCL2 on RNA levels and concentration of CCL2 in the supernates of unstimulated PBMC were significantly higher in patients with SLD as compared with SSc patients

\section{Streszczenie}

Cel pracy: Śródmiąższowa choroba płuc (ŚChP) jest główną przyczyną zgonów wśród chorych na twardzinę układową (TU). CCL2 jest chemokiną o silnym działaniu prozapalnym oraz stymulującym procesy włóknienia. Celem pracy było porównanie ekspresji CCL2 w hodowlach komórek jednojądrowych krwi obwodowej (KJKO) u chorych na TU z oraz bez ŚChP.

Materiał i metody: Do badania zakwalifikowano 23 chorych na TU (11 z i 12 bez ŚChP). Grupę kontrolną stanowiło 12 zdrowych osób odpowiednio dobranych pod względem ptci i wieku. Ekspresję RNA oceniano metodą łańcuchowej reakcji polimerazy w czasie rzeczywistym, a stężenie CCL2 - za pomocą komercyjnie dostępnych zestawów ELISA w hodowlach KJKO bez i po stymulacji LPS.

Wyniki: Zarówno spontaniczna ekspresja RNA CCL2, jak i stężenia CCL2 w nadsączach w KJKO od chorych ze ŚChP była istotnie wyższa w porównaniu z chorymi bez ŚChP. Stymulacja za pomocą LPS powo-

Address for correspondence:

prof. dr hab. med. Otylia Kowal-Bielecka, Department of Rheumatology and Internal Diseases, Medical University of Bialystok, Sklodowskiej-Curie 24 A, 15-276 Bialystok, tel. +48 85746 84 82, e-mail: otyliab@tlen.pl

Submitted: 18.03 .2013 
without SLD. Stimulation with LPS led to dramatic increase in expres sion of CCL2 RNA and CCL2 concentrations in PBMC cultures in all subjects studied. LPS-stimulated expression of CCL2 RNA and the concentrations of CCL2 in LPS-stimulated PBMC cultures were significantly higher in patients with SLD than in those without SLD. Patients with SLD had significantly higher skin core and higher frequency of anti-topoisomerase I antibodies as compared with SSc patients without SLD. However, in multivariate regression analyses including disease subset (diffuse or limited SSc) and the presence of anti-topoisomerase I antibody, spontaneous and LPS-stimulated expression of CCL2 RNA, and the concentration of CCL2 in LPS-stimulated PBMC were independently associated with the presence of SLD.

Conclusions: We show that expression of $\mathrm{CCl} 2$ in PBMC is associated with the risk SLD in patients with SSc. The results of our study indicate that increased expression of $\mathrm{CCl} 2$ by PBMC might play a role in the pathogenesis of SLD.

\section{Introduction}

Systemic sclerosis (SSc, scleroderma) is a chronic autoimmune disease characterized by excessive fibrosis of the skin and internal organs [1, 2]. Chronic and irreversible damage of the lungs is the primary cause of mortality due to SSc [1]. The pathogenesis of SSc is complex and several biologically active mediators have been shown to participate in the pathogenesis of fibrosis in SSc patients [2].

One of the mediators implicated in the pathogenesis of SSc is CCL2 chemokine (also referred to as monocyte chemotactic protein-1 - MCP-1). Elevated serum CCL2 levels have been found in SSc patients in comparison to healthy controls [3, 4]. Moreover, elevated levels of CCL2 correlated with the extent of skin fibrosis, indicating its important role in SSc pathogenesis [4]. In a longitudinal study the variations of CCL2, but not other chemokines, were significantly associated with the variations of skin thickness score and lung function assessed as vital capacity [3]. These observations suggest that CCL2 may be considered a serological marker of the activity of skin and lung involvement in patients with SSc. In addition the study emphasizes the role of CCL2 in the pathogenesis of both skin and lung fibrosis in SSc patients. Elevated levels of CCL2 were found in bronchoalveolar lavage fluid (BALF) of patients with interstitial lung disease in comparison to those without interstitial lung disease [5]. Concentration of CCL2 correlated with lung function impairment as evaluated by spirometry and high-resolution computed tomography (HRCT) [6].

CCL2 belongs to the CC chemokine family and exerts a broad range of pro-inflammatory and pro-remodeling functions [5]. Beside its potent chemoattractant effects CCL2 functions as a strong pro-fibrotic mediator [5]. Human lung fibroblasts cultured in vitro with CCL2 release elevated amounts of interleukin 6 (IL-6) but synthesis of transforming growth factor $\beta$ (TGF- $\beta$ ) or vascular endothelial growth factor (VEGF) is not affected [7]. This results in enhanced fibroblast survival by inhibiting apop- dowała wzrost ekspresji CCL2 u wszystkich osób zakwalifikowanych do badania. Zarówno ekspresja RNA CCL2, jak i stężenia CCL2 w nadsączach KJKO stymulowanych LPS od chorych ze ŚChP były istotnie wyższe w porównaniu z tymi parametrami u chorych bez ŚChP. Zakres zmian skórnych oraz częstość występowania przeciwciał przeciwko topoizomerazie I (anty-topo I) były istotnie wyższe u chorych ze ŚChP w porównaniu z chorymi bez ŚChP. Jednakże w analizie regresji wielokrotnej obejmującej postać choroby (TU uogólniona lub ograniczona) oraz obecność anty-topo I, spontaniczna oraz stymulowana LPS ekspresja RNA dla CCL2, a także stężenia CCL2 w komórkach stymulowanych LPS były niezależnymi predykatorami ŚChP u chorych na TU.

Wnioski: Wykazano, że wzmożona ekspresja CCL2 w KJKO wiąże się z obecnością ŚChP u chorych na TU. Wyniki pracy wskazują, że zwiększona ekspresja CCL2 w KJKO może odgrywać rolę w patogenezie ŚChP w przebiegu TU.

tosis through an IL-6/STAT3 dependent mechanism which in turn may contribute to the development and maintenance of lung fibrosis [7]. CCL2 augments fibroblast proliferation and collagen synthesis during keloid formation in the skin [8]. Skin fibroblasts stimulated with CCL2 release increased amounts of matrix metalloproteinases (MMP) including MMP-1 and MMP-2 as well as MMP inhibitor (TIMP-1), which play an important role in tissue remodeling [9]. Involvement of CCL2 in upregulation of genes coding for extracellular matrix components in the skin of SSc patients has also been described [10]. The pro-fibrotic effect of CCL2 in that clinical setting seems to result from both the direct action of CCL2 on skin structural cells and from its indirect effect via accummulation of immune cells. In addition, CCL2 plays a role in recruitment of fibrocytes to sites of inflammation [11].

Experimental animal studies support the critical role of CCL2 in tissue fibrosis, emphasizing the critical role of CCL2 in pathogenesis of pulmonary fibrosis. In several disease models CCL2 has been shown to be required for development of pulmonary fibrosis and silencing CCL2 resulted in significant attenuation of lung pathology [12, 13].

CCL2 is produced by many cell types, including fibroblasts, epithelial, smooth muscle and endothelial cells, but monocytes/macrophages are the main sources of CCL2 [14]. It was therefore of interest to evaluate production of CCL2 by peripheral blood mononuclear cells (PBMC) of SSC patients paying particular attention to possible associations between in vitro production of CCL2 and the presence of interstitial lung disease.

\section{Material and methods}

Twenty-three patients fulfilling the ACR classification criteria for SSc and/or the definition of early SSc, as proposed by LeRoy and Medsger, were included in the study $[15,16]$. Only patients who had not taken any immunosuppressive therapies or in whom immunosuppressive the- 
rapies had been stopped at least 6 months before blood collection were considered eligible. Systemic sclerosis patients were classified as having diffuse SSc (dSSc) or limited SSc (ISSc) based on criteria of LeRoy et al. [17] and evaluated as described previously [18]. Duration of the disease was calculated from the first non-Raynaud's symptom attributable to SSc. In agreement with generally accepted criteria, early SSc was defined as shorter than 3 years in patients with dSSc or shorter than 5 years duration in patients with ISSc measured from the first non-Raynaud symptom. Skin involvement was assessed using the modified Rodnan skin score (mRSS). The presence of scleroderma interstitial lung disease (SLD) was defined based on the presence of features of interstitial fibrosis and/or "ground glass" opacifications in high resolution computed tomography (HRCT) of the lungs. The severity of lung invoIvement was evaluated by measurements of the forced vital capacity (FVC) and diffusing capacity of the lungs for carbon monoxide (DLCO). Pulmonary hypertension was defined as pulmonary artery systolic pressure (PASP) higher than $45 \mathrm{~mm} \mathrm{Hg}$, as measured by echo-Doppler. Patients without tricuspid regurgitation were considered as having normal pulmonary artery pressure. The presence of antinuclear antibodies (ANA) and anti-centromere (ACA) antibodies was assessed by indirect immunofluorescence on
Hep-2 cells, while the presence of anti-topoisomerase I (antitopo I) antibodies was assessed by an enzyme-linked immunosorbent assay technique. The control group consisted of 12 age- and sex-matched healthy subjects ( $\mathrm{HC})$. Clinical characteristics of the patients and controls are given in Table I.

The study protocol was approved by the local ethics committee and all patients gave appropriate informed consent.

\section{Cell isolation and culture}

Heparin anticoagulated peripheral blood samples were obtained from the cubical vein between 7 and 8 a.m. after the patient had fasted for at least 10 hours. Peripheral blood mononuclear cells (PBMC) were isolated from the whole blood using density gradient centrifugation. The isolated PBMC were resuspended in RPMI medium supplemented with $5 \%$ fetal calf serum at a density of $10^{5}$ cells $/ \mathrm{ml}$ and cultured at $37^{\circ} \mathrm{C}$ under $5 \% \mathrm{CO}_{2}$ with lipopolysaccharide $(10 \mu \mathrm{g} / \mathrm{ml})$ or without any stimulation. Cells for RNA isolation were harvested from the cultures after 6 -hour incubation. The cells after separation were immediately lysed in lysis buffer and stored at $-80^{\circ} \mathrm{C}$ until RNA isolation. Supernatants for evaluation of CCL2 production were collected from cultures run for 24 hours and stored at $-80^{\circ} \mathrm{C}$ until measurements.

Table I. Clinical characteristics of the patients with systemic sclerosis (SSc), SSc patients with scleroderma interstitial lung disease (SLD), those without SLD and the control group

\begin{tabular}{|lcccc|}
\hline Parameter & $\begin{array}{c}\text { Controls } \\
(n=12)\end{array}$ & $\begin{array}{c}\text { SSc patients } \\
(n=23)\end{array}$ & $\begin{array}{c}\text { SSc patients with SLD } \\
(n=11)\end{array}$ & $\begin{array}{c}\text { SSc patients without SLD } \\
(n=12)\end{array}$ \\
\hline female/male ratio & $10 / 2$ & $18 / 5^{*}$ & $8 / 3$ & $10 / 2$ \\
\hline age & $45 \pm 12$ & $46 \pm 12^{*}$ & $49 \pm 15 \pm 10$ \\
\hline disease duration in years & $1.54 \pm 1.27$ & $1.39 \pm 0.95$ & $1.69 \pm 1.53$ \\
\hline dSSc/lSSc & $12 / 11$ & $7 / 4$ & $5 / 7$ \\
\hline mRSS & $15.57 \pm 11.90$ & $20.82 \pm 11.00$ & $10.75 \pm 11^{\wedge}$ \\
\hline ANA positive (\%) & $21(91)$ & $11(100)$ & $10(83)$ \\
\hline Anti-topo I positive (\%) & $13(57)$ & $9(82)$ & $4(33)^{\wedge}$ \\
\hline ACA positive (\%) & $3(13)$ & 0 & $3(25)$ \\
\hline Raynaud's phenomenon (\%) & $23(100)$ & $11(100)$ & $11(100)$ \\
\hline SLD in HRCT & $11(49)$ & $85.67 \pm 17.12$ & $107.10 \pm 10.27^{\wedge}$ \\
\hline FVC (\% of predicted) & $96.85 \pm 17.48$ & $53.81 \pm 22.41$ & $84.64 \pm 20^{\wedge}$ \\
\hline DLCO (\% of predicted) & $71.43 \pm 25.79$ & $1(9)$ & 0 \\
\hline pulmonary hypertension (\%) & $1(4)$ & & 0 \\
\hline
\end{tabular}

*non-significant versus controls, ${ }^{\wedge} p<0.05$ vs SSc patients with SLD

ACA - anti-centromere antibodies, ANA - antinuclear antibodies, dSSC - diffuse systemic sclerosis, HRCT - high resolution computed tomography, ISSC - limited systemic sclerosis, mRSS - modified Rodnan skin score, SLD - scleroderma lung disease 


\section{Biochemical assays}

Total RNA was isolated from cellular pellets using the RNeasy Mini Kit (Qiagen GmbH, Germany). Reverse transcription was performed using the High Capacity cDNA Reverse Transcription Kit (Applied Biosystems, USA) according to the manufacturer's instructions. Evaluation of CCL2 expression was performed using TaqMan-based realtime polymerase chain reaction (RT-PCR) with a CCL2 specific probe, NM-002982.3. As a control, expression of a housekeeping gene, $\beta 2$-microglobulin, was evaluated using a specific probe, NM_004048.2. The reaction started with a 10 -minute initial denaturation at $95^{\circ} \mathrm{C}$, which was followed by 40 thermal cycles, each consisting of 15 -second denaturation at $95^{\circ} \mathrm{C}$ and 60 -second elongation at $60^{\circ} \mathrm{C}$. The procedure was performed using $A B I$ Prism 7900HT (Applied Biosystems, USA).

Expression of individual genes was calculated using the comparative threshold cycle (CT) method (Fig. 1). The CT value represents the number of cycles which have to be run to reach the exponential phase of amplification of the evaluated product. The CT of the target gene was compared to that of a housekeeping gene $\left(\Delta \mathrm{CT}=\mathrm{CT}_{\text {target gene }}\right.$

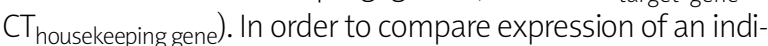
vidual sample the percentage of housekeeping gene expression was calculated according to the formula: $\mathrm{R}=$ $=2^{-\Delta C T} \times 100 \%$.

Evaluation of CCL2 concentration in the supernatants was performed using commercially available ELISA kits (R\&D Systems, Minneapolis, MO, USA).

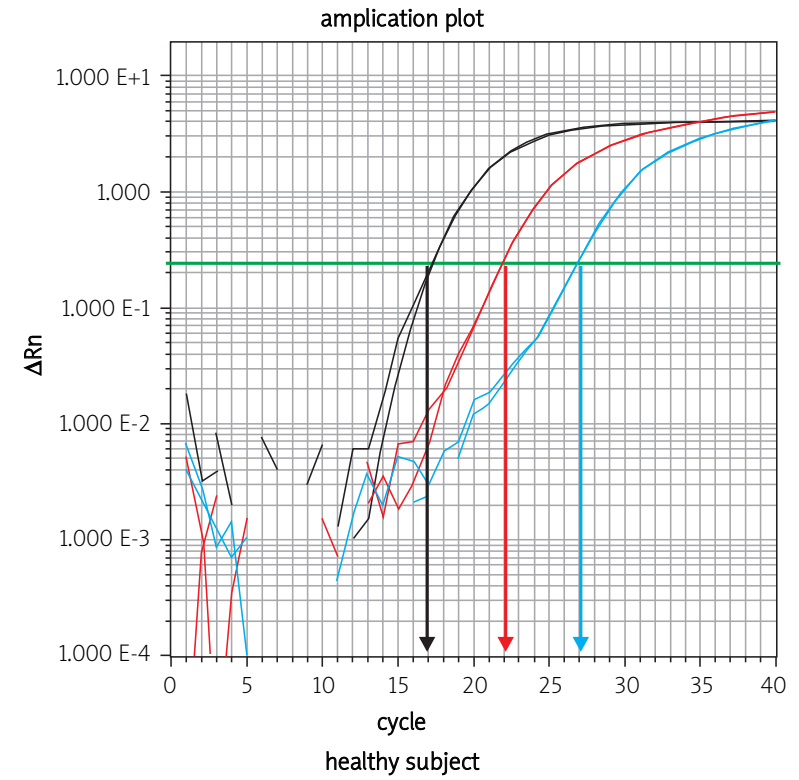

\section{Statistical analysis}

For statistical analysis the ANOVA test and Fisher's test were used as appropriate. Potential relationships between individual parameters were assessed using multivariate regression analyses. $P$ values $<0.05$ were considered as significant. Values are given as mean and standard deviations (SD) unless stated otherwise.

\section{Results}

High resolution computed tomography of the lungs revealed features of SLD in 11 out of 23 (49\%) SSc patients included in the study. There was no significant difference of sex and age distribution between SSc patients with and without SLD or between SSc patients and HC - Table I. Patients with SLD had significantly greater skin involvement and worse results of the pulmonary function tests as compared with SSc patients without SLD. Anti-topo I antibodies were significantly more frequent in patients with SLD $(82 \%)$ than in those without pulmonary fibrosis $33 \%$, $p<0.05)$. Anti-centromere antibodies were found in $3(25 \%)$ of the SSc patients without SLD and in none of the SSC patients with SLD. The mean spontaneous expression of CCL2 by PBMC on RNA level was the greatest in patients with SLD $(R=3.78 \pm 2.82 \%)$, being significantly greater than in SSc patients without SLD $(R=0.98 \pm 0.595 \%$; $p<0.01)$, which in turn was significantly greater than in $\mathrm{HC}(R=0.18$ $\pm 0.097 \%$; $p<0.001$ ) (Figs. 1 and 2).

Similarly, the mean CCL2 concentration in supernatants of cultures without LPS stimulation was the greatest in

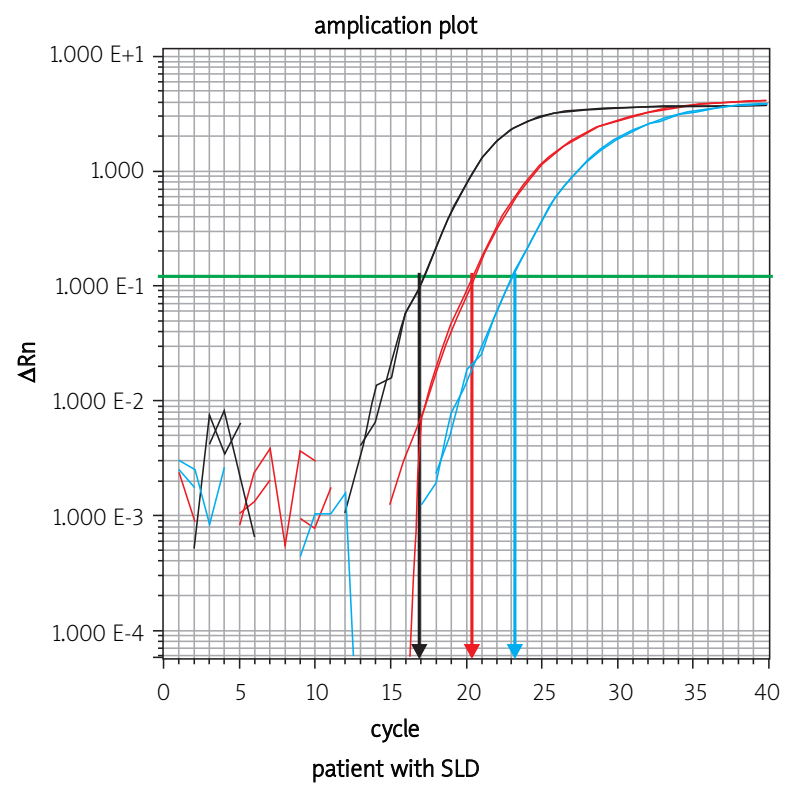

Fig. 1. Representative results of RT-PCR analysis of CCL2 expression in individual subjects. Left - healthy subject, right - SSc patient with SLD. Black - expression of $\beta 2$-microglobulin, blue - expression of CCL2 without any stimulation, red - expression of CCL2 after LPS stimulation. 


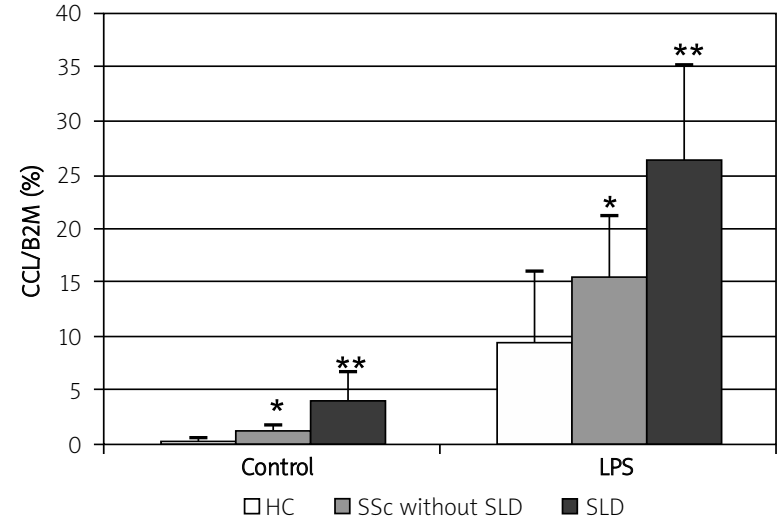

${ }^{*} p<0.05$ vs. HC, ${ }^{* *} p<0.05$ vs. SSC patients without SLD"

Fig. 2. Expression of CCL2 expressed as \% of $\beta 2$-microglobulin expression.

patients with SLD $(398 \pm 282 \mathrm{pg} / \mathrm{ml})$, being significantly greater than in SSc patients without SLD $(159.8 \pm 121.6 \mathrm{pg} / \mathrm{ml}$; $p<0.05)$, which in turn was greater than in $\mathrm{HC}(37.6 \pm 10.2$ $\mathrm{pg} / \mathrm{ml} ; p<0.01$ ) (Fig. 3).

In multivariate regression analysis including form of the disease (dSSc vs ISSc) and anti-topo I antibodies, which are well-known risk factors of SLD, CCL2 expression on RNA levels $(\beta=0.44, p=0.04)$ but not the concentration of CCLS $(\beta=0.33, p=0.11)$ was independently associated with the presence of SLD.

Stimulation with LPS led to dramatic up-regulation of CCL2 expression and increase of CCL2 concentrations in PBMC supernates in both SSC patients and HC (Figs. 1, 2 and 3). In cultures stimulated with LPS the greatest mean expression of CCL2 RNA was detected in SLD patients $(R=26.3 \pm 8.7 \%)$, which was significantly greater than in SSc patients without SLD $(R=15.3 \pm 5.8 \%$; $p<0.01)$, which was greater than in $\mathrm{HC}(R=9.49 \pm 6.58 \% ; p<0.05)$. In cultures stimulated with LPS the mean concentration of CCL2 was the greatest in patients with SLD $(23833 \pm 9767 \mathrm{pg} / \mathrm{ml})$, being significantly greater than in SSc patients without SLD (15023 $\pm 5925 \mathrm{pg} / \mathrm{ml}$; $p<0.05)$, which was significantly greater than in HC $(9690 \pm 6576 \mathrm{pg} / \mathrm{ml} ; p<0.05)$. In multivariate regression analysis including form of the disease (dSSc vs ISSc) and anti-topo I antibodies both LPS-stimulated CCL2 expression on RNA levels $(\beta=0.51, p<0.01)$ and the concentration of CCLs in PBMC $(\beta=0.44, p<0.05)$ were independently associated with the presence of SLD.

\section{Discussion}

In this study we have demonstrated that PBMC are an important source of CCL2 in patients with SSc. Moreover, we have shown that PBMC from SSc patients are characterized by enhanced production of CCL2 both spontaneously and upon LPS stimulation and the increased pro-

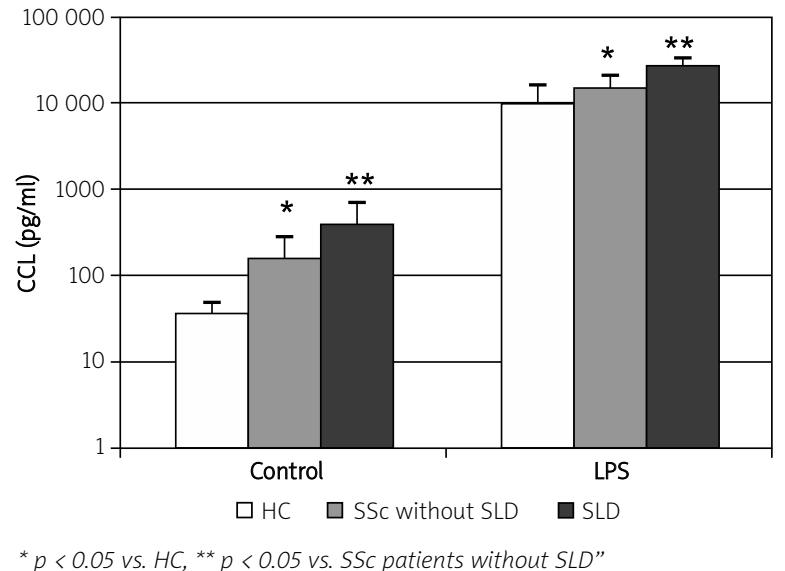

Fig. 3. Concentration of CCL2 in cell culture supernatants.

duction is associated with up-regulation of CCL2 expression on the transcriptional level.

Many exogenous factors and endogenous mediators affect production of CCL2. Its expression is induced by platelet-derived growth factor (PDGF) [19], tumor necrosis factor $\alpha($ TNF- $\alpha)$ [20], interferon $\gamma($ IFN- $\gamma)$ [21], and IL-1 $\beta$ [22]. Eicosanoids including prostaglandin E2 (PGE2), TXA2 and 15(S)-HETE also induce the expression of MCP-1 [23-25].

In patients with SSc elevated production of several pro-inflammatory cytokines has been described [2]. The increased production of proinflammatory cytokines such as IL-1 $\beta$ or TNF- $\alpha$ may induce secretion of CCL2; however, elevated production of CCL2 seen spontaneously and after stimulation may argue for more complex mechanisms responsible for elevated synthesis of CCL2 by PBMC. In fact, several genetic and epigenetic factors affecting expression of CCL2 have been described. Among genetic factors an A-2578G single nucleotide polymorphism which is functional and affects expression of CCL2 is associated with susceptibility to some chronic diseases such as asthma or lupus nephritis [26-29]. Moreover, altered histone acetylation plays a role in the regulation of CCL2 expression, indicating an important role of epigenetic factors in CCL2 expression [30].

Of interest, the highest secretion of CCL2 in response to LPS seen in patients with SLD may explain the predisposition of localization of inflammation and fibrosis to the lungs due to particular exposure of that organ to bacterial products and vital involvement of mononuclear phagocytes in the inflammatory response in the respiratory tract. However, it cannot be inferred from our study whether elevated expression of CCL2 by PBMC is directly invoIved in the pathogenesis of SSc or it reflects general abnormalities in CCL2 production seen also in other cells such as epithelium or fibroblasts. Further studies are required to clarify the mechanisms responsible for involvement of CCL2 in the pathogenesis of SSC. 
In summary, our study demonstrates that peripheral blood mononuclear cells of SSc patients may participate in augmented synthesis of CCL2 through up-regulation of CCL2 gene transcription. In addition, it shows that among SSc patients enhanced production of CCL2 by those cells is associated with SLD, a most ominous organ involvement.

\section{Authors declare no conflict of interests.}

\section{References}

1. Tyndall AJ, Bannert B, Vonk M, et al. Causes and risk factors for death in systemic sclerosis: a study from the EULAR Scleroderma Trials and Research (EUSTAR) database. Ann Rheum Dis 2010; 69: 1809-1815.

2. Abraham DJ, Krieg T, Distler J, et al. Overview of pathogenesis of systemic sclerosis. Rheumatology (Oxford) 2009; 48 (Suppl 3): iii3-7.

3. Hasegawa M, Fujimoto M, Matsushita T, et al. Serum chemokine and cytokine levels as indicators of disease activity in patients with systemic sclerosis. Clin Rheumatol 2011; 30: 231-237.

4. Bandinelli F, Del Rosso A, Gabrielli A, et al. CCL2, CCL3 and CCL5 chemokines in systemic sclerosis: the correlation with SSc clinical features and the effect of prostaglandin E1 treatment. Clin Exp Rheumatol 2012; 30 (2 Suppl 71): S44-49.

5. Rose CE Jr, Sung SS, Fu SM. Significant involvement of CCL2 (MCP-1) in inflammatory disorders of the lung. Microcirculation 2003; 10: 273-288.

6. Schmidt K, Martinez-Gamboa L, Meier S, et al. Bronchoalveoloar lavage fluid cytokines and chemokines as markers and predictors for the outcome of interstitial lung disease in systemic sclerosis patients. Arthritis Res Ther 2009; 11: R111.

7. Liu X, Das AM, Seideman J, et al. The CC chemokine ligand 2 (CCL2) mediates fibroblast survival through IL-6. Am J Respir Cell Mol Biol 2007; 37: 121-128.

8. Liao WT, Yu HS, Arbiser JL, et al. Enhanced MCP-1 release by keloid CD14+ cells augments fibroblast proliferation: role of MCP- 1 and Akt pathway in keloids. Exp Dermatol 2010; 19: e142-150.

9. Yamamoto T, Eckes B, Mauch C, et al. Monocyte chemoattractant protein-1 enhances gene expression and synthesis of matrix metalloproteinase- 1 in human fibroblasts by an autocrine IL-1 $\beta$ loop. J Immunol 2000; 164: 6174-6179.

10. Distler JH, Jüngel A, Caretto D, et al. Monocyte chemoattractant protein 1 released from glycosaminoglycans mediates its profibrotic effects in systemic sclerosis via the release of interleukin-4 from T cells. Arthritis Rheum 2006; 54: 214-225.

11. Moore BB, Kolodsick JE, Thannickal VJ, et al. CCR2-mediated recruitment of fibrocytes to the alveolar space after fibrotic injury. Am J Pathol 2005; 166: 675-684.

12. Inoshima I, Kuwano K, Hamada N, et al. Anti-monocyte chemoattractant protein-1 gene therapy attenuates pulmonary fibrosis in mice. Am J Physiol Lung Cell Mol Physiol 2004; 286: L1038-L1044.

13. Moore BB, Paine R 3rd, Christensen PJ, et al. Protection from pulmonary fibrosis in the absence of CCR2 signaling. J Immunol 2001; 167: 4368-4377.

14. Yoshimura T, Robinson EA, Tanaka S, et al. Purification and amino acid analysis of two human monocytes chemoattractants produced by phytohemagglutinin-stimulated human blood mononuclear leukocytes. J Immunol 1989; 142: 1956-1962.
15. Subcommittee for scleroderma criteria of the American Rheumatism Association Diagnostic and Therapeutic Criteria Committee. Preliminary criteria for the classification of systemic sclerosis (scleroderma). Arthritis Rheum 1980; 23: 581-590.

16. LeRoy EC, Medsger TA Jr. Criteria for the classification of early systemic sclerosis. J Rheumatol 2001; 28: 1573-1576.

17. LeRoy EC, Black C, Fleischmajer R, et al. Scleroderma (systemic sclerosis): classification, subsets and pathogenesis. J Rheumatol 1988; 15: 202-205.

18. Bielecki M, Kowal K, Bernatowicz P, et al. Increased production of a proliferation-inducing ligand (APRIL) by the peripheral blood mononuclear cells predicts worse prognosis in patients with systemic sclerosis. Reumatologia 2012; 50: 461-471.

19. Ping D, Boekhoudt G, Boss JM. Trans-Retinoic acid blocks platelet-derived growth factor-BB-induced expression of the murine monocyte chemoattractant-1 gene by blocking the assembly of a promoter proximal Sp1 binding site. J Biol Chem 1999; 274: 31909-31916.

20. Ping D, Jones PL, Boss JM. TNF regulates the in vivo occupancy of both distal and proximal regulatory regions of the MCP-1/JE gene. Immunity 1996; 4: 455-469.

21. Zhou ZH, Chaturvedi P, Han YL, et al. IFN-gamma induction of the human monocyte chemoattractant protein (hMCP)-1 gene in astrocytoma cells: functional interaction between an IFN-gammaactivated site and a GC-rich element. J Immunol 1998; 160: 3908-3916.

22. Martin T, Cardarelli PM, Parry GC, et al. Cytokine induction of monocyte chemoattractant protein-1 gene expression in human endothelial cells depends on the cooperative action of NF-kappa B and AP-1. Eur J Immunol 1997; 27: 1091-1097.

23. Nakayama T, Mutsuga N, Yao L, Tosato G. Prostaglandin E2 promotes degranulation-independent release of MCP-1 from mast cells. J Leukoc Biol 2006; 79: 95-104.

24. Li X, Tai HH. Activation of thromboxane A2 receptor (TP) increases the expression of monocyte chemoattractant protein-1 (MCP-1)/chemokine (C-C motif) ligand 2 (CCL2) and recruits macrophages to promote invasion of lung cancer cells. PLoS One 2013; 8: e54073.

25. Potula HS, Wang D, Quyen DV, et al. Src-dependent STAT-3mediated expression of monocyte chemoattractant protein-1 is required for 15(S)-hydroxyeicosatetraenoic acid-induced vascular smooth muscle cell migration. J Biol Chem 2009; 284: 31142-31155.

26. Rovin BH, Lu L, Saxena R. A novel polymorphism in the MCP-1 gene regulatory region that influences MCP-1 expression. Biochem Biophys Res Commun 1999; 259: 344-348.

27. Wright EK Jr, Page SH, Barber SA, Clements JE. Prep1/Pbx2 complexes regulate CCL2 expression through the -2578 guanine polymorphism. Genes Immun 2008; 9: 419-430.

28. Szalai C, Kozma GT, Nagy A, et al. Polymorphism in the gene regulatory region of MCP-1 is associated with asthma susceptibility and severity. J Allergy Clin Immunol 2001; 108: 375-381.

29. Tucci M, Barnes EV, Sobel ES, et al. Strong association of a functional polymorphism in the monocyte chemoattractant protein 1 promoter gene with lupus nephritis. Arthritis Rheum 2004; 50: $1842-1849$

30. Aung HT, Schroder K, Himes SR, et al. LPS regulates proinflammatory gene expression in macrophages by altering histone deacetylase expression. FASEB J 2006; 20: 1315-1327. 